\title{
CHALLENGES IN THE USE OF VIDEO LARYNGOSCOPES
}

\author{
Branka Maldini ${ }^{1,2}$, Iljaz Hodžović ${ }^{3}$, Tatjana Goranovićc,4 and Jasna Mesarićc \\ ${ }^{1}$ Department of Anesthesiology and Intensive Medicine, Sestre milosrdnice University Hospital Center, Zagreb; \\ ${ }^{2}$ Osijek School of Medicine, Josip Juraj Strossmayer University, Osijek, Croatia; ${ }^{3}$ Anaesthesia, Intensive Care \\ and Pain Medicine, Wales School of Medicine, Cardiff University, Cardiff, United Kingdom; ${ }^{4}$ Department \\ of Anesthesiology and Intensive Medicine, University Department for Tumors, Sestre milosrdnice University \\ Hospital Center; ${ }^{5}$ Agency for Quality and Accreditation in Health Care and Social Welfare, Zagreb, Croatia
}

\begin{abstract}
SUMMARY - Despite the lack of uniformity and the need of further investigation, video laryngoscopy continues to gain popularity both inside and outside the operating room. It has quickly become a first line strategy for potential and/or encountered difficult intubation. It is well established that video laryngoscope improves laryngeal view as compared with direct laryngoscopy in patients with suspected difficult intubation and simulated difficult airway scenarios. For novices and experienced anesthesiologists alike, video laryngoscopy is easy to use and the skills involved are easy to master. However, it is important to say that video laryngoscopes may be used in a variety of clinical scenarios and settings because of the video laryngoscope design offering an alternative intubation technique in both anaesthetized and awake patients. The aim of this article is to show and highlight clinical situations in which the use of video laryngoscope is a challenge for an experienced anesthesiologist in solving the airway. Challenges in the use of video laryngoscope with which we deal and encounter in everyday clinical practice that are discussed in this paper are intubation in the prehospital setting and emergency departments, intubation in Intensive Care Unit, intubation in a patient with cervical spine immobilization, and awake video laryngoscopy-assisted tracheal intubation in the obese. We also point out the important role of video laryngoscope as a tool for teaching and training in airway education. Training and education in difficult airway management is essential to improve patient safety at endotracheal intubation in emergency situation.
\end{abstract}

Key Words: Intubation, Intratracheal; Laryngoscopy - Instrumentation; Laryngoscopes; Video Recording-Instrumentation; Critical Care; Intensive Care Units; Cervical Vertebrae; Immobilization; Obesity; Education

\section{Introduction}

Airway management has always been a priority for physicians of all eras ${ }^{1,2}$. Every physician must have skill for appropriate airway management. Difficult laryngoscopy has been reported to occur in $6 \%-10 \%$ of intubations ${ }^{2,3}$. Consequently, each intervention which could improve successful intubation, especially when

Correspondence to: Prof. Branka Maldini, $M D, P h D$, Department of Anesthesiology and Intensive Medicine, Sestre milosrdnice University Hospital Center, Vinogradska c. 29, HR-10000 Zagreb, Croatia

E-mail: branka.maldini@gmail.com

Received: February 27, 2015, accepted: September 16, 2015 performed by unskilled persons, may be warranted in these situations ${ }^{3}$.

Direct laryngoscopy remains the gold standard technique as an effective means to secure the airway. It is a complicated technical skill with a variable learning curve requiring training, experience, and regular practice to acquire and maintain ${ }^{4-6}$. Direct laryngoscopy requires a direct line of sight to align airway axes (oral-pharyngeal-laryngeal) for optimal glottic visualization. Manipulations used to align the three axes include head extension, neck flexion and laryngeal manipulation. These maneuvers may have adverse implications such as significant hemodynamic disturbance, cervical instability, injury to 
oral and pharyngeal tissues, as well as dental damage ${ }^{6,7}$.

The approach to airway management has undergone dramatic transformation since the advent of video laryngoscopy. Video laryngoscope in contrast to direct laryngoscopy allows good exposure of the glottis without the need to align oral, pharyngeal and tracheal axes ${ }^{6}$. Video laryngoscope utilizes a camera at the distal tip of the laryngoscope blade with an LCD display requiring minimal lifting force for visualization, thus making it less likely to stimulate stress response and induce local tissue injury ${ }^{7}$. Video laryngoscopes have quickly gained on popularity as an intubation device in a variety of clinical scenarios and settings, as well as in the hands of airway experts and non-experts ${ }^{6}$.

Clinicians usually use video laryngoscope when difficulty with endotracheal intubation is anticipated or following failed direct laryngoscopy ${ }^{5}$. There is also no reason why video laryngoscopy cannot be used routinely for intubations and in fact should be used more frequently to gain the necessary experience, so it can be used confidently for difficult intubation $s^{1-5}$. Although the use of video laryngoscopy may facilitate and speed achievement of competence in intuba$\operatorname{tion}^{3,4}$, video laryngoscope is uncommonly used as the primary intubating device ${ }^{3,4}$. In their work, Silverberg and Kory ${ }^{1}$ showed the most common reasons why video laryngoscope should not be used as the primary intubating device. They assessed the use of video laryngoscopy among internal medicine fellowship programs training physicians in critical care medicine and found that video laryngoscope was reportedly used as the primary intubating device in $16 \%$ of programs. The video scope was never used in $9 \%$ of programs, despite being available. Other barriers against using video laryngoscopy as primary devices included the need to train fellows on multiple devices and difficulties in getting video laryngoscopy equipment cleaned. They also conclude that video laryngoscopy improves intubation success and reduces esophageal intubations compared to direct laryngoscopy ${ }^{1}$.

The aim of this article is to provide a topical review of the literature on indirect rigid fiberoptic techniques in the visualization and management of the airway in critically ill patients outside the operating room, in prehospital setting and emergency departments, as well as in the intensive care unit (ICU); in patients with cervical spine fractures or other cervical pathology; and awake tracheal intubation in obesity. These procedures are a major challenge because of both challenging patient conditions and variability in the provider's airway management skills. Each particular device features may offer advantages or disadvantages, depending on the situation the anesthesiologist has to deal with ${ }^{4-6}$.

\section{Advantages and Disadvantages of Video Laryngoscopy}

There are a number of advantages and disadvantages associated with the use of video laryngoscopes:

\section{Advantages}

- Improved glottic visualization without the need to align three airway axes, especially in scenarios with limited neck mobility ${ }^{6}$;

- Higher endotracheal intubation rate with nonexpert and expert laryngoscopists; an effective tool for those that intubate infrequently, as well as for students and residents yet learning to intubate; less cervical manipulation ${ }^{2,3}$;

- Allows others to view the screen and/or help facilitate endotracheal intubations ${ }^{6}$;

- Can be used as a tool for awake airway evaluation prior to intubation ${ }^{7}$;

- Can provide an official record of the tracheal intubation for medico legal purposes and to inform on the future airway management ${ }^{2,4}$.

\section{Disadvantages}

- Difficulty in passing endotracheal tube despite improved glottic visualization (especially with angulated blade), termed 'laryngoscopy paradox'4;

- Increased intubation time when compared to Macintosh laryngoscope in patients with normal airway";

- Variable learning curve ${ }^{1}$;

- Potential weakening in development and maintenance of direct laryngoscopy skill set, especially when there is no expert in airway management ${ }^{2,4}$;

- Potential for false sense of security and lack of preparation for difficult airway ${ }^{4}$; 
- Two-dimensional view with loss of depth perception can lead to significant injury to the upper airway;

- Obscured view by fogging and secretions/blood in the airway ${ }^{4}$;

- Video laryngoscopes are significantly more expensive than Macintosh laryngoscope ${ }^{7}$.

\section{Challenges in the Use of Video Laryngoscope}

\section{Intubation in the prehospital setting and emergency departments}

Patients requiring endotracheal intubations (ETI) in nonoperating room or off-site settings (emergence department - ED, prehospital) are typical emergency situations associated with hemodynamic compromise. These patients often meet ASA III or IV classification, and have a much higher risk of difficult laryngoscopy and intubation, even when operators have adequate airway skills ${ }^{8,9}$. Furthermore, the risk of complications associated with poor glottic visualization (Cormack and Lehane grades III or IV) is twice as high outside versus inside the operating room ${ }^{3,4,10}$. The risks compound further when inexperienced providers are responsible for securing the airway under such challenging conditions. Consequently, there is an increased rate of complications during urgent endotracheal intubation compared with intubations in the operating room ${ }^{10,11}$. Airway management in the emergency department is therefore a major challenge because of both challenging patient conditions and variability in the provider's airway management skills. More recently, the use of rigid video laryngoscopy in the emergency medicine setting has grown significantly. Patients with cervical spine abnormalities may benefit from the augmented laryngeal view afforded by video laryngoscopy. Early observational studies reported less frequent use of video laryngoscopy compared with direct laryngoscopy and similar success rate when the techniques were compared ${ }^{11,12}$. In more recent observational studies, video laryngoscopy seems to be used more frequently overall, and with greatest frequency in patients predicted to be difficult to intubate ${ }^{13-14}$. In the study by Sakles et $a l^{14}, \mathrm{C}-\mathrm{MAC}$ was associated with a greater proportion of successful intubation rate and greater proportion of Cormack-Lehane grade I or II views. In an- other study by Sakles et al. ${ }^{15}$, GlideScope had a higher overall success rate and lower number of esophageal complications compared with direct laryngoscopy. Similarly, Mosier et al. ${ }^{16}$ showed a higher success rate with GlideScope video laryngoscope (78\%) compared with direct laryngoscopy (68\%) for emergency airway management, even when video laryngoscopy was used more frequently in those with predictors of difficult direct laryngoscopy. Furthermore, these data suggest that more frequent use of video laryngoscopes by emergency medicine providers may improve success rate of these devices in this setting. However, further research is needed to evaluate the use of video laryngoscopy in a prospective randomized fashion for the emergency medicine patient with trauma.

\section{Intubation in Intensive Care Unit}

Airway management in ICU patients is challenging and frequently associated with life threatening complications ${ }^{17,18}$. The incidence of difficult endotracheal intubations is higher in the ICU than in the operating room ${ }^{19}$. New video laryngoscope devices are proposed to improve airway management ${ }^{7,8}$. However, most of the studies comparing video laryngoscope with standard laryngoscope were performed in operating rooms $s^{4,5}$. Competence in airway management is an essential skill for all critical care physicians. The Accreditation Council for Graduate Medical Education (ACGME) states that critical care trainees "must demonstrate competence in procedural and technical skills in airway management and endotracheal intubation"19. Such skills in urgent endotracheal intubation are typically gained in the ICU, where almost all intubations are high-risk events due to the urgency in securing the airway ${ }^{3,10}$. Consequently, there is an increased rate of complications associated with tracheal intubations in the ICU setting compared with intubations in the operating room ${ }^{4}$. Anticipating difficult intubation is a challenging issue in the ICU: difficult intubation is very frequent (up to 23\%) and associated with severe life-threatening complications ${ }^{20}$. Yong et $a l .^{18}$ showed that the incidence of difficult intubation was dramatically decreased by using video laryngoscopy for intubation in the ICU. This systematic review showed a decrease in the incidence of difficult intubation, difficult laryngoscopy and esophageal intubation. The use of video laryngoscopy, however, did not 
reduce the incidence of severe hypoxemia, cardiovascular collapse or airway injury ${ }^{18}$.

In contrast to the operating room, space is very limited in the ICU. Access to patient's head is difficult because of equipment positioned around the bed, such as syringe pumps and hemodialysis machine. Additionally, position of the patient is often inadequate and accompanying comorbidities can make laryngoscopy challenging 9 .

Recently, a strategy for endotracheal intubation in the ICU has been evaluated ${ }^{21,22}$. In most cases, endotracheal intubation is an emergency procedure: in $39 \%$ with real urgency and in additional $48 \%$ with a relative urgency ${ }^{20}$. Multiple attempts for endotracheal intubation are often necessary to secure the patient's airway in the ICU setting ${ }^{21}$. At the same time, multiple intubation attempts performed outside the operating room are known to increase the risk of lifethreatening complications such as hypoxia $(7 \mathrm{x})$, severe hypoxia $(14 \mathrm{x})$, regurgitation $(7 \mathrm{x})$, aspiration (4x), bradycardia $(4 \mathrm{x})$ and cardiac arrest $(7 \mathrm{x})^{20,21}$. Unrecognized esophageal intubation is frequently observed in the ICU and is associated with a high mortality of up to $90 \%{ }^{4,21}$.

The choice of induction medication in ICU can modify patient outcome and survival. In a randomized, controlled trial, patients received either etomidate or ketamine for intubation ${ }^{22}$. The authors found that intubation conditions were similar in both groups; however, patients receiving etomidate as a single dose presented with adrenal insufficiency. Septic patients showed a trend towards increased mortality. The authors conclude that ketamine should be preferred in patients with sepsis. Etomidate is currently not recommended for use in trauma patients since it was associated with a higher risk of acute respiratory distress syndrome, multiorgan failure and prolonged ICU stay ${ }^{23}$.

In a prospective study of 247 consecutive patients over a two-year period, the use of the C-MAC ${ }^{\varpi}$ with Macintosh shaped blade improved visualization of the glottis during airway management in the $\mathrm{ICU}^{24}$. In patients with at least one predictor for difficult airway, not only glottic view but also success rate of endotracheal intubation at first attempt was higher in the C-MAC group compared to Macintosh laryngoscopy $(79 \% \text { vs. } 56 \%)^{24}$.
As most of the studies included a relatively small number of patients, additional large randomized studies are needed to determine if video laryngoscope use in the ICU setting can reduce intubation related respiratory and cardiovascular complications. Training and education in (difficult) airway management is essential to improve patient safety in the $\mathrm{ICU}^{20-24}$.

\section{Cervical spine concerns}

The incidence of cervical spine injury in patients with blunt trauma is estimated to be $1.8 \%{ }^{14}$. The most common level of injury is $\mathrm{C} 2$ vertebra, followed by $\mathrm{C} 6$ and $\mathrm{C} 7$ levels. The patient with head trauma is more likely to have a cervical spine injury than the patient experiencing blunt trauma without associated head injury ${ }^{25,26}$. Tracheal intubation must be performed with utmost care in patients with cervical spine fractures or other cervical pathology to prevent cord damage $^{26}$. The use of semi-rigid cervical collar or manual in-line stabilization (MILS) of the cervical spine to prevent neck movements may result in poor laryngeal view on direct laryngoscopy leading to difficulty in intubation $^{26}$. Indirect laryngoscopy techniques have been studied to try balance the need to limit cervical motion and overcome the difficulty of obtaining laryngeal views when MILS is applied. Although flexible fiberoptic intubation may expose cervical spine to the least traction, this procedure requires significant skill and a cooperative patient if it is to be performed on an awake patient. For the anesthetized patient, this procedure still often requires jaw thrust, which may expose the patient to cervical traction ${ }^{14}$. Video laryngoscopes may be easier to learn than flexible fiberoptic intubation and offer improvement in terms of intubation difficulty compared with direct laryngoscopy. As such, their use has grown for the management of patients with cervical spine precautions ${ }^{13}$.

According to the fluoroscopic comparisons between GlideScope and Macintosh, GlideScope does not significantly decrease the movement of cervical spine, but improves glottic visualization in patients with MILS $^{6-30}$. Furthermore, in patients with ankylosing spondylitis, the GlideScope provided better laryngoscopic view than Macintosh and allowed nasotracheal intubation in the majority of these patients $^{31,32}$. Malik et al. ${ }^{32}$ demonstrated that both GlideScope and AWS reduced the Intubation Difficulty 
Score, improved $\mathrm{C} / \mathrm{L}$ grade and reduced the need for optimization maneuvers in patients with cervical spine immobilization, compared with Macintosh. In addition, AWS performed better than Macintosh in patients with restricted neck mobility, even when a gum elastic bougie was used with Macintosh to aid intubation $^{32}$. Videofluroscopic studies showed that the upper cervical spine movement was significantly decreased during intubation with AWS compared with Macintosh and McCoy direct laryngoscopes in patients with in-line stabilization ${ }^{34}$. The manikin study by Aziz et al., which compared the performance of Storz V-Mac to Macintosh in a 'stiff neck scenario' showed that the percentage of glottic opening was significantly improved with V-Mac ${ }^{35}$. Bharti et al..$^{25}$ presented a prospective study to compare the effectiveness of Macintosh, McCoy and TruView laryngoscopes for ease of intubation in patients with immobilized cervical spine. They report that the TruView laryngoscope reduced the intubation difficulty score and improved the glottis view, compared with $\mathrm{Ma}-$ cintosh and McCoy laryngoscopes in patients with immobilized cervical spine. They conclude that the TruView laryngoscope is advantageous to Macintosh and $\mathrm{McCoy}$ laryngoscopes for tracheal intubation in patients with immobilized cervical spine ${ }^{25}$.

Key points: The application of MILS facilitates safe intubation, but makes direct laryngoscopy more difficult. The use of video laryngoscopes for the management of the patient with cervical spine immobilization is growing because the techniques are easy to learn and video laryngoscopes facilitate better laryngeal view. The improvement of the laryngeal view seems to translate into a higher intubation success rate. Furthermore, conditions common to trauma medicine such as active regurgitation, abnormal patient position, and cervical spine immobilization are factors that are known to increase the risk of difficult intubation. Patients with these conditions may benefit from newer airway technologies.

\section{Awake video laryngoscopy-assisted tracheal intubation in obesity}

The management of the obese patient's airway is also challenging because the obese body habitus makes mask ventilation and tracheal intubation technically difficult ${ }^{5}$. Patients with morbid obesity (body mass index $\geq 40 \mathrm{~kg} / \mathrm{m}^{2}$ ) are also commonly associated with difficult intubation than normal weight patients $^{5}$. In addition, the decreased functional residual capacity of obese patients limits the duration of normal oxygen saturation during apnea. It is the reason why tracheal intubation in this patient population is often performed before the induction of general anesthesia, while maintaining spontaneous respiration ${ }^{5,37}$. Fiberoptic bronchoscopes require extensive training and practice ${ }^{33}$. Furthermore, they are rather expensive and the presence of edema, excess airway tissue, and secretions or blood in the pharynx or larynx make fiberoptic bronchoscope intubation of the trachea difficult, or even impossible ${ }^{38,39}$.

Moore $e t a l .{ }^{36}$ in their study described awake tracheal intubation using the GlideScope video laryngoscope in 50 patients undergoing bariatric surgery. After sedation and topical anesthesia of the airway, awake tracheal intubation was attempted, assisted by video laryngoscopy and terminated if there was severe gagging, coughing or inadequate laryngeal view. They conclude that video laryngoscopy has several advantages when compared with the use of bronchoscopes, the 'gold standard' for awake intubations. As video laryngoscopes are tools that are operated in a similar fashion as conventional laryngoscope, they are relatively easy to use. Video laryngoscopes are less expensive than bronchoscopes, are portable and are easier to clean and store ${ }^{2}$. As video laryngoscopes are rigid, they can push away excess tissue, secretions or blood, thereby allowing better view of the vocal cords. The inspiration of aerosolized local anesthetics provides adequate airway anesthesia in the majority of patients. Moore et al. ${ }^{36}$ also point out that because video laryngoscope is larger than bronchoscope, it exerts more tractions on the tongue and upper airway, and may therefore induce gagging independent of the type of the local anesthetic used. They conclude that awaken tracheal intubation assisted by video laryngoscopy could be a useful tool for the management of the morbidly obese patient's airway. Curtis ${ }^{38}$ has commented on the study by Moore et al. ${ }^{36}$, that awaken patients might be at an increased risk of palatal trauma secondary to coughing/gagging making subsequent attempts at intubation potentially more difficult. A1though awake video laryngoscopy-assisted tracheal intubation may be a useful tool in the morbidly obese, 
it is important that practitioners are aware of the potential pitfalls associated with the technique and plan their airway management accordingly ${ }^{37-39}$.

\section{Video Laryngoscope as a Teaching/Training Tool}

Anesthesiologists like video laryngoscopes because they make their life somewhat more serene. Video laryngoscopes are easy to use, and skills involved are easy to master by either novices or experienced anesthesiologists ${ }^{13}$.

By facilitating learning of both traditional laryngoscopy and video laryngoscopy, video laryngoscopes may improve safety by avoiding many unnecessary intubation attempts ${ }^{2}$. Projecting what the operator sees on the screen creates a new dynamic interaction during airway management. The entire anesthesia team can assess progress in real time, which enhances communication and cohesion of the group and improves coordination between the assistant(s) and the operator ${ }^{1}$.

The high-quality, enlarged image on its monitor allows the instructor to demonstrate the anatomy of the upper airway and the procedures of laryngoscopy and intubation to novices. Moreover, when a novice is attempting intubation, the instructor is able to watch the monitor and provide feedback ${ }^{1}$. Storz is a video laryngoscope that is appropriate for intubation teaching because it has a standard Macintosh blade, thus the intubation is identical to the traditional one. With video laryngoscope, the 'peer over my shoulder' teaching method is displaced, considerable time is saved and many unnecessary intubation attempts can be avoided $^{4}$. Video-assisted instruction with Storz may shorten the learning curve of direct laryngoscopy and intubation for novices ${ }^{7}$.

Teaching line-of-site techniques are difficult because the teacher cannot share the view with the learner. Video laryngoscopy provides a shared view for the teacher and the student. In the case of video modifications of traditional laryngoscope blades such as the Storz C-MAC, the learner can practice a traditional direct laryngoscopic technique, while the teacher can view what the student sees ${ }^{1,2}$.

In extreme emergency situations, patients may need to undergo endotracheal intubation while in non-supine position. The anesthesiologist has to cope with tracheal intubations in non- standard positions, therefore, there is a need for adequate training in anesthesia skills, thereby classic direct laryngoscopy and indirect video laryngoscopy should be practiced on manikins before the trainees actually practice anesthesia on patients in operating theatres.

Indeed, patients may be trapped in positions other than supine (e.g., motor vehicle accidents, explosions, construction accidents), or be exposed to external penetrating injuries (stabbings, gunshot wounds, impalement), whereby the patient cannot resume most familiar supine position ${ }^{37}$. Van Zundert and Van Zundert ${ }^{40}$ report that the use of video laryngoscopy in this setting provides several advantages. First, it may make impossible intubation possible or even easier. Second, video laryngoscopy allows a much better view of the pharyngeal and laryngeal structures than direct laryngoscopy. Third, it is a better educational tool than the 'look over my shoulder' and allows the instructor to see in detail what the trainee is doing while performing intubation.

Furthermore, palatal injury and pharyngeal injury have been related to video laryngoscope ${ }^{4}$. A possible reason is that, when the tracheal tube is inserted in the oral cavity, the laryngoscopist is looking at the monitor, thus losing the image of the tube for a few seconds. Training could minimize such adverse events. This is the reason why a training period is necessary to ensure appropriate use in order for the user to obtain its full benefit ${ }^{43-45}$.

In our hospital, anesthetic skills are available to train junior doctors in tracheal intubation of patients in non-standard position including both direct and indirect laryngoscopy. There are a number of advantages to using models and simulators to teach airway management with video laryngoscopes ${ }^{40-45}$. This allows for skill training outside the operating room. It also limits contact with patients at the time when the novice has only rudimentary skill, and it may also reduce the potential for patient injury ${ }^{37}$.

We used the C-MAC (Karl Storz, Tuttlingen, Germany) video laryngoscope for teaching based solely on its availability in our department and for comfort and experience with its use, but we agree that our result may have been different using other video laryngoscopes with which we were less familiar. Unlike video laryngoscopes with acute angulated blades, it is possible to see the glottis in two ways: 
the first in direct view of the glottis with the naked eye, and the second in indirect view from the monitor with the help of a miniature camera at the tip of the blades. Further research is clearly required to evaluate and compare the strengths and weakness of various methods and equipment used in non-supine patients in extreme emergency situations, with the aim of improving the success rate of endotracheal intubation.

\section{Conclusion}

The approach to airway management has undergone dramatic transformation since the advent of video laryngoscopy. It is very clear that the integration of new technology and techniques into anesthesia practice has a potential to reduce patient injury and increase safety. Difficult intubation is a challenging issue and is associated with severe life-threatening complications. The implementation of a quality-improvement process for airway management using a video laryngoscope would be associated with a decreased incidence of difficult laryngoscopy and/or difficult intubation. The greater effectiveness of video laryngoscopes associated with multi-person visualization could enhance overall patient safety during airway management. Anesthesiologists have already incorporated video laryngoscope as an adjunct to alternative difficult intubation. It has further been suggested that video laryngoscope may improve safety by avoiding many unnecessary attempts and facilitate learning of both direct and indirect laryngoscopy. It is clear that video laryngoscopes expand the armamentarium not only for anesthesiologists but also for healthcare providers who are potentially involved in airway management.

Video laryngoscopes have the potential to increase patient safety by facilitating learning, teaching, and success of tracheal intubation.

\section{References}

1. Silverberg MJ, Kory P. Survey of video laryngoscopy use by U.S. critical care fellowship training programs. Ann Am Thorac. 2014;11(8):1225-9. doi: 10.1513/AnnalsATS.201405$189 \mathrm{OC}$

2. Chemsian RV, Bhananker S, Ramaiah R. Videolaryngoscopy. Int J Crit Illn Inj Sci. 2014;4(1):35-41. doi: 10.4103/22295151.128011
3. Thong SY, Lim Y. Video and optic laryngoscopy assisted tracheal intubation - the new era. Anaesth Intensive Care. 2009;37:219-33.

4. Martin LD, Mhyre JM, Shankas AM, Tremper KK, Kheterpal S. 3,423 emergency tracheal intubations at a university hospital: airway outcomes and complications. Anesthesiology. 2011;14:42-8. doi: 10.1097/ALN.0b013e318201c415.

5. Maassen R, Lee R, Hermans B, Marcus M, van Zundert A. A comparison of three videolaryngoscopes: the Macintosh laryngoscope blade reduces, but not replace, routine stylet use for intubation in morbidly obese patients. Anesth Analg. 2009;109:1560-5. doi: 10.1213/ANE.0b013e3181b7303a.

6. Huford W. The video revolution: a new view of laryngoscopy. Respir Care. 2010;55:1036-45.

7. Paolini JB, Donati F, Drolet P. Review Article: Video-laryngoscopy: another tool for difficult intubation or a new paradigm in airway management? Can J Anaesth. 2013;60:18491. doi: 10.1007/s12630-012-9859-5.

8. Griesdale De, Bosma TL, Kurth T, Isac G, Chittock DR. Complications of endotracheal intubation in the critically ill. Intensive Care Med. 2008;34:1835-42. doi: 10.1007/s00134008-1205-6.

9. Platts-Mills TF, Campagne D, Chinnock B, Snowden B, Glickman LT, Hendey GW. A comparison of GlideScope video laryngoscopy versus direct laryngoscopy intubation in the emergency department. Acad Emerg Med. 2009;16:86671. doi: 10.1111/j.1553-2712.2009.00492.x.

10. Choi HJ, Kang HG, Lim TH, Chung HS, Cho J, Oh YM, et al. Endotracheal intubation using a GlideScope video laryngoscope by emergency physicians. A multicentre analysis of 345 attempts in adult patients. Emerg Med J. 2010;27:380-2. doi: 10.1136/emj.2009.073460.

11. Laurent SC, De Melo AE, Alexander-Williams JM. The use of the McCoy laryngoscope in patients with simulated cervical spine injuries. Anesthesia. 1966;51:74-5.

12. Aziz M. Use of video-assisted intubation devices in the management of patients with trauma. Anesthesiology. 2013;31:157-66. doi: 10.1016/j.anclin.2012.10.001.

13. Goldberg W, Mueller C, Panacek E, Tigges S, Hoffman JR, Mower WR, et al. Distribution and patterns of blunt traumatic cervical spine injury. Ann Emerg Med. 2001,38:17-21.

14. Sakles JC, Moseir JM, Chiu S, Keim SM. Tracheal intubation in the emergency department: a comparison of GlideScope video laryngoscopy to direct laryngoscopy in 822 intubations. J Emerg Med. 2012;42:400-5. doi: 10.1016/j. jemermed.2011.05.019.

15. Sakles JC, Mosier J, Chiu S, Cosentino M, Kalin L. A comparison of the C-MAC video laryngoscope to the Macintosh direct laryngoscope for intubation in the emergency department. Ann Emerg Med. 2012;60:739-48. doi: 10.1016/j. annemergmed.2012.03.031.

16. Moseir JM, Stolz U, Chiu S, Sakles JC. Difficult airway management in the emergency department: GlideScope videolar- 
yngoscopy compared to direct laryngoscopy. J Emerg Med 2012;42:629-34. doi: 10.1016/j.jemermed.2011.06.007.

17. Heuer JF, Barwing TA, Barwing J, Russo SG, Bleckmann E, Quintel $\mathrm{M}$, et al. Incidence of difficult intubation in intensive care patients. Analysis of contributing factors. Anaesth Intensive Care. 2012;40:120-7.

18. Yong AD, Clavieras N, Conseil M, Coisel Y, Moury PH, Pouzeratte $\mathrm{Y}$, et al. Implantation of combo videolaryngoscope for intubation in critically ill patients: a before-after comparative study. Intensive Care Med. 2013;39:2144-52. doi: 10.1007/s00134-013-3099-1.

19. Accreditation Council for Graduate Medical Education. ACGME program requirements for Graduate Medical Education in Critical Care Medicine. 2011 Oct 1 (revised 2013 July; accessed 2014 May 1). Available from: http://www. acgme.org/acgmeweb/Portals/0/PFAssets/2013-PR-FAQPIF/142_critical_care_int_med-0713201.

20. Bowles TM, Freshwater-Turner DA, Janssen DJ, Peden CJ; RTIC Severn Group. Out-of-theatre tracheal intubation: prospective multicentre study of clinical practice and adverse events. Br J Anaesth. 2011;107:687-92. doi: 10.1093/bja/ aer251.

21. Cook TM, Woodall N, Harper J, Benger J; Fourth National Audit Project. Major complications of airway management in the UK: results of the Fourth National Audit Project of the Royal College of Anaesthetists and the Difficult Airway Society. Part 2: Intensive care and emergency departments. Br J Anaesth. 2011;106:632-42. doi: 10.1093/bja/aer059.

22. Jabre P, Combes X, Lapostolle F, Dhaouadi M, Ricard-Hibon A, Vivien B, et al. Etomidate versus ketamine for rapid sequence intubation in acutely ill patients: a multicentre randomised controlled trial. Lancet. 2009;374:293-300. doi: 10.1016/S0140-6736(09)60949-1

23. Bernhard M, Matthes G, Kanz KG, Waydhas C, Fischbacher M, Fischer M, et al. Emergency anesthesia, airway management and ventilation in major trauma. Background and key messages of the interdisciplinary S3 guidelines for major trauma patients. Anaesthesist. 2011;60:1027-40. doi: 10.1007/s00101-011-1957-1.

24. Noppens RR, Geimer S, Eisel N, David M, Piepho T. Endotracheal intubation using the C-MAC video laryngoscope or the Macintosh laryngoscope: a prospective, comparative study in the ICU. Crit Care. 2012;16:R103. doi: 10.1186/ cc11384.

25. Bharti N, Arora S, Panda BP. A comparison of McCoy, TruWiew and Macintosh laryngoscopes for tracheal intubation in patients with immobilized cervical spine. Saudi J Anesth. 2014;8(2):188-92. doi: 10.4103/1658-354X.130705.

26. Goutcher CM, Lochhead V. Reduction in mouth opening with semi-rigid cervical collars. Br J Anesth. 2005;95:344-8.

27. Bilgin H, Bozkurt M. Tracheal intubation using the ILMA, $\mathrm{C}$-Trach or McCoy laryngoscope in patients with simulated cervical spine injury. Anesthesia. 2006;61:685-91.
28. Gabbott DA. Laryngoscopy using the McCoy laryngoscope after application of a cervical collar. Anesthesia. 1996;51:8124.

29. Turkstra TP, Crean RA, Pelz DM, Gelb AW. Cervical spine motion; a fluoroscopic comparison during intubation with Lighted Stylet, and Macintosh laryngoscope. Anesth Analg. 2005;101:910-5.

30. Robitaille A, Williams SR, Tremblay MH, Guilbert F, Theriault $\mathrm{M}$, Drolet P. Cervical spine motion during tracheal intubation with manual in-line stabilization; direct laryngoscopy versus GlideScope videolaryngoscopy. Anesth Analg. 2008;106:935-41. doi: 10.1213/ane.0b013e318161769e.

31. Laih, Chen IH, Chen A, Hawangy FY, Lee Y. The use of the GlideScope for tracheal intubation in patients with ankylosing spondylitis. Br J Anaesth. 2006;97:412-22.

32. Malik MA, Maharay CH, Harte BH, Laffey JG. Comparison of Macintosh, Truview EVO2, GlideScope and Airway scope laryngoscope use in patients with cervical spine immobilization. Br J Anaesth. 2008;101:723-30. doi: 10.1093/bja/ aen231.

33. Komatsu R, Kamata K, You J, Sessler DI, Kasuya Y. Airway scope for tracheal intubation in the lateral position. Anesth Analg. 2011;112:868-74. doi: 10.1213/ ANE.0b013e31820c7cdf.

34. Maruyama K, Yamada T, Kawakami R, Kamata T, Yokochi M, Hara K. Upper cervical spine movement during intubation: fluoroscopic comparison of the AirWay Scope, McCoy laryngoscope and Macintosh laryngoscope. Br J Anesth. 2008;100:120-4.

35. Azis MF, Headly D, Kheterpal S, Fu RF, Dillman D, Brambrink AM. Routine clinical practice effectiveness of the GlideScope in difficult airway management: an analysis of 2,004 GlideScope intubations, complications, and failures from two institutions. Anesthesiology. 2011;114:34-41. doi: 10.1097/ ALN.0b013e3182023eb7.

36. Moore AR, Schircker T, Court O. Awake videolaryngoscopyassisted tracheal intubation of the morbidly obese. Anesthesia. 2012;67:232-5. doi: 10.1111/j.1365-2044.2011.06979.x.

37. Maldini B, Goranović T, Vučić M, Kovač J, Baranović S, Letica-Brnadić R. Difficult airway management at Sestre milosrdnice University Hospital Center. Acta Clin Croat. 2012;51:473-76.

38. Curtis R. Awake videolaryngoscopy-assisted tracheal intubation in the morbidly obese. Anesthesia 2012;67:796-7. doi: 10.1111/j.1365-2044.2012.07186.x.

39. Maldini B, Novotny Z, Letica-Brnadić R, Brkljačić A, Bartolek D. Difficult airway management with Bonfils fiberscope in case of emergency: acute abdomen with ileus. Acta Clin Croat. 2012;51:483-7.

40. Van Zundert TCR, Van Zundert AAJ. Tracheal intubation of patients in non-standard positions requires training. Minerva Anesthesiol. 2013;79(6):679-82.

41. Aziz M, Dillman D, Kirsch JR, Brambrink A. Video laryn- 
goscopy with the Macintosh video laryngoscope in simulated prehospital scenarios by paramedic students. Prehosp Emerg Care. 2009;13:251-5. doi: 10.1080/10903120802706070.

42. Peirovifar A, Mahmoodpoor A, Golzari SE, Soleimanpour H, Eslampour Y, Fattahi V. Efficacy of video-guided laryngoscope in airway management skills of medical students. J Anaesthesiol Clin Pharmacol. 2014;30(4):488-91. doi: 10.4103/0970-9185.142810.

43. Vanderbilt AA, Mayglothling J, Pastis NJ, Franzen D. A review of the literature: direct and video laryngoscopy with simulation as educational intervention. Adv Med Educ Pract. 2014;5:15-23. doi: 10.2147/AMEP.S51963.

44. Crosby E, Fcarcsi AL. Innovations in anesthesia education: the development and implementation of a resident rotation advanced airway management. Can J Anesth. 2009;56:93959. doi: 10.1007/s12630-009-9197-4.

45. Komatsu R, Kamata K, Hoshi I, Sessler DI, Ozaki M. Airway Scope and gum elastic bougie with Macintosh laryngoscope for tracheal intubation in patients with simulated restricted neck mobility. Br J Anesth. 2008;101:863-9. doi: 10.1093/bja/aen288.

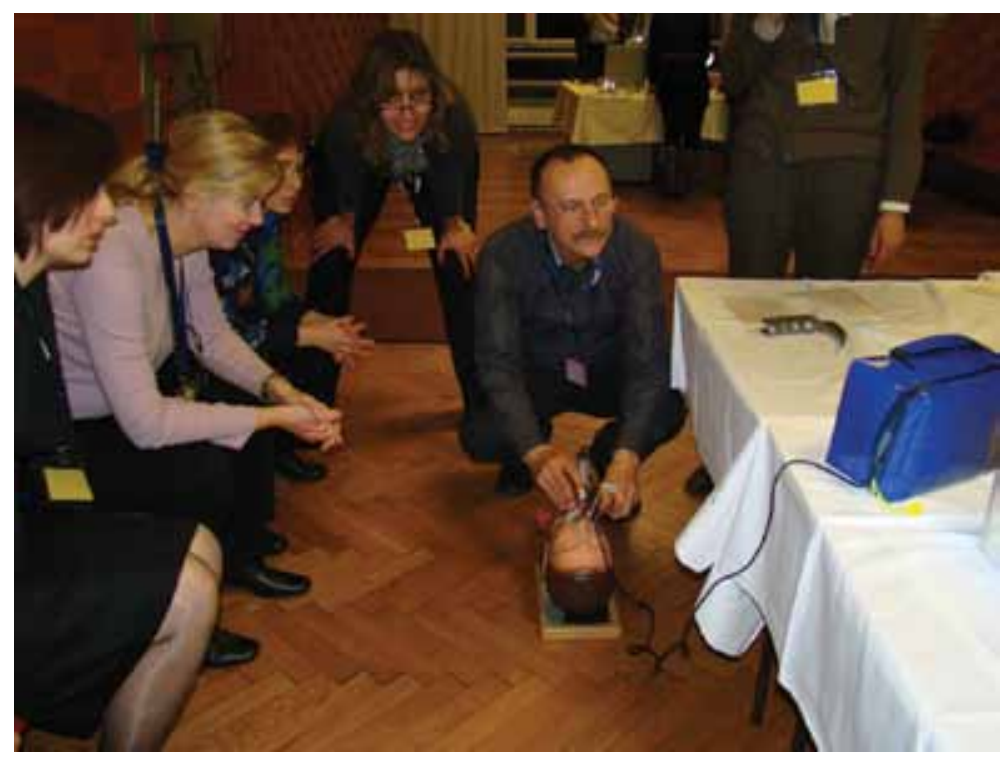

Fig. 1. Intubation of manikins with video laryngoscopy in non-standard position.

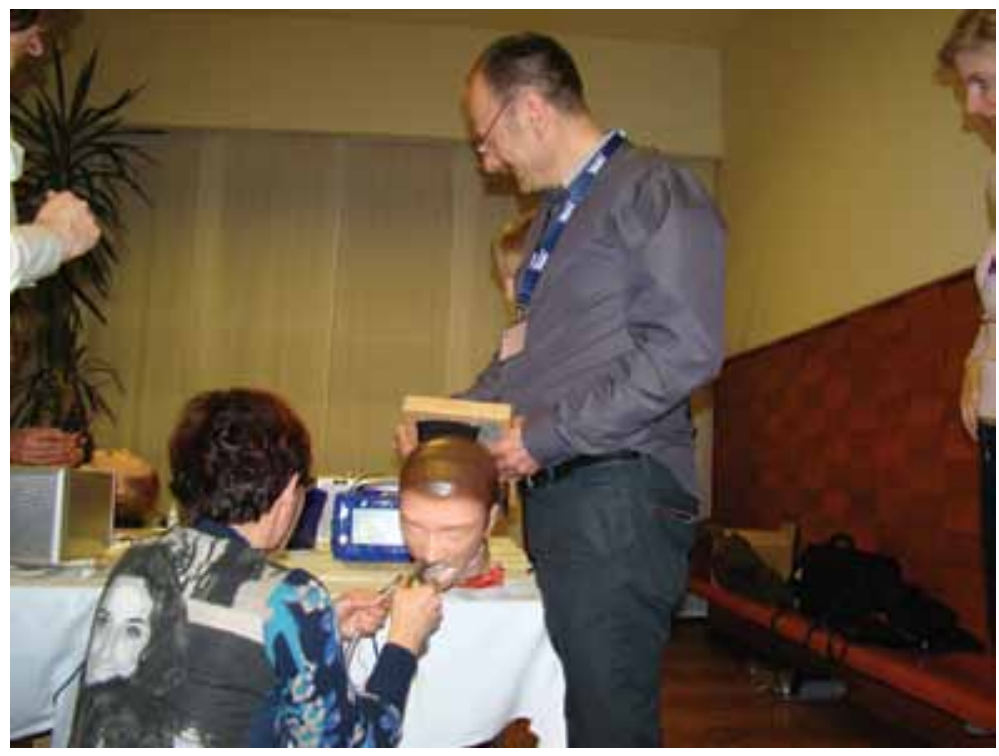

Fig. 2. Intubation of manikins with video laryngoscopy in non-standard position. 


\section{Sažetak}

\section{IZAZOVI U UPORABI VIDEO LARINGOSKOPA}

\section{B. Maldini, I. Hodžović, T. Goranović iJ. Mesarić}

Unatoč nedostatku ujednačenosti proizvoda na tržištu i potrebe za daljnjim istraživanjem, video laringoskopi i dalje su popularni unutar i izvan operacijske dvorane. Oni su postali prva linija u strategiji za potencijalne i/ili teške intubacije. Dobro je poznato da video laringoskopi poboljšavaju prikaz larinksa u usporedbi s direktnom laringoskopijom u bolesnika sa sumnjom na otežanu intubaciju i kod simuliranih teških pristupa dišnome putu. Za početnike i iskusne anesteziologe podjednako video laringoskop je jednostavan za korištenje, a vještine koje su potrebne za rad s njim su lako savladive. Osobitost video laringoskopa je da se može koristiti u različitim kliničkim situacijama s obzirom na to da su osmišljeni tako da nude alternativnu tehniku i u anesteziranih i kod budnih bolesnika. U ovom radu želimo ukazati na kliničke situacije u kojima korištenje video laringoskopa predstavlja izazov za iskusne anesteziologe u rješavanju otežanoga pristupa dišnome putu. Specifične indikacije za korištenje video laringoskopa u svakodnevnoj kliničkoj praksi su: intubacija u pre-hospitalnim uvjetima i hitnim odijelima; intubacija u jedinici intenzivnog liječenja; intubacija bolesnika s imobiliziranom vratnom kralježnicom te budna intubacija u pretilih bolesnika. U radu također ističemo važnu ulogu laringoskopa u edukaciji prikaza i tehničkog savladavanja pristupa dišnome putu. Obuka i obrazovanje u zbrinjavanju otežanoga dišnog puta je nužna radi poboljšanja sigurnosti bolesnika u hitnim stanjima kod kojih je neophodna uspostava dišnoga puta.

Ključne riječi: Intubacija, intratrahealna; Laringoskopija - instrumentacija; Laringoskopi; Video snimanje - instrumentacija; Intenzivna skrb; Jedinice intenzivnog liječenja; Kralježnica, vratna; Imobilizacija; Debljina; Edukacija 